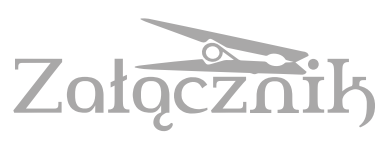

\title{
PROUST AND THE OLLENDORFF'S METHOD
}

\author{
JAN ZIELIŃSKI
}

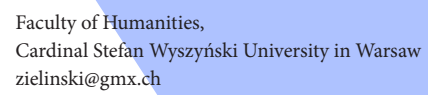

Cooperation between Proust and the Ollendorff family of Parisian publishers who came from Rawicz in Wielkopolska (Western Poland) spanned at least twenty years: it started with an article written for a free-of-charge advertising newspaper, published by Paul Ollendorff's publishing house, which appeared in July 1893, through an attempt of publishing by Ollendorff in 1902 his translation of Ruskin by and further through a more or less successful cooperation with Ollendorff's daily „Gil Blas” (1904) up to the failed attempt at publishing the first volume of his masterpiece at the beginning of 1913. Let us take a look at all of its stages.

\section{3: „GRATIS-JOURNAL”}

As the name indicates, it was a free-of-charge advertising news-sheet featuring information about new books published by Paul Ollendorff's company. We know that Proust published in the newspaper by accident, due to the fact that the daughter of the author of the book discussed by him, Count de Saussine, encountered Proust's manuscript among papers left by her father and handed it over to his editors.

Henri du Pont de Gault-Saussine (1859-1940) was an engineer by profession and a musician by passion. He lived in Paris at Hôtel Créqui (16, rue de Saint-Guillaume) and he used to organize staging of little known or completely forgotten musical compositions (in 1902 he staged Le mariage secret by Cimarosa and in 1912 Stabat Mater by Pergolesi). The Count's residence was also frequented by modern musicians, such as Fauré, Franck, d'Indy, Ravel, well-known writers including Bourget, Anna de Noailles, Henri de Régnier, and aristocrats like Countess Greffuhle or Princess Polignac. Proust visited him too and immortalized the atmosphere of these meetings, combining aristocracy of the spirit with aristocracy of the blood, in a short 
story dedicated to the Count and entitled Éventail (A Fan, 1893). Among quite malicious portraits painted on the fan, Proust also included his alter ego in the person of one T..., who describes his room to the lady of the house and the addressee of the text, which is covered with tar in order to resemble a ship's cabin. The narrator comments (and let us remember that Proust, in order to isolate himself from noise, asked to have his room lined with cork):

Your disdainful smile shows that you do not value this crippled imagination which is not satisfied with projecting all visions of the universe into a naked room and which treats art and beauty in such miserably material way (Proust 1971a: 52).

Henri de Saussine also composed chamber music and more complex musical pieces. His opera buffa L'Amour-Marmiton was staged in 1899. His other works were staged by Reynaldo Hahn and Ferdinand de Madrazo, who were also friends with Proust. The Count was also the author of philosophical dialogues, several comedies and two novels: Le Nez de Cléopâtre (Cleopatra's Nose, 1893) and Le Prisme (The Prism, 1895) (see: Bertrand 1996: 614-616).

Proust's text in "Gratis-Journal” published by Paul Ollendorff referred to the former and was immensely flattering. Having praised the successful combination of the sheer absolute with the meaningful concrete, Proust compares the author of the novel to Zola, Stendhal, Tolstoy and Shakespeare. At the end, making an allusion to the author's musical fascinations, he indicates a transposition of Wagner's leitmotiv in the form of Cleopatra's nose from the title.

It is quite probable that Proust wrote the text 'for old time's sake', at the request of the author of the novel. Nevertheless, it is impossible to completely rule out the possibility that the advertisement review was just one of several and possibly many anonymous advertising texts which the young writer had written on the order by the Parisian publisher with Polish roots. Their identification turns out to be very difficult due to the absence of manuscripts and the fact that the advertising news-sheet of Ollendorff is a true ava raris.

A highly flattering letter about the second novel of de Saussine, published by Ollendorff, offers some insight as to the nature of these texts. Proust sent it in 1895 to Tristan Bernard, in the introduction referring to his share in 
the magazine called „Revue Blanche” (published in Paris by the Natanson brothers from Warsaw):

Dear Sir,

One of the former editors of "Revue Blanche” would like to express a wish; namely, he would like your magazine to run a piece about a very worthy work of Mr. Saussine, Prisme, published over a month ago. I do not believe that my attachment to the author of the work multiplies the benefits of the work, which is one of the most interesting, most complex and strongest in the recent years.

In my opinion only he, a musician equally erudite and zealous as a man of letters, could have written this doubly artistic work. I believe that you are going to read it with great pleasure and that you will have the honor of announcing it worthily. Forgive me if I am making an impression as if I was giving you advice (...) (Proust, Corr., Vol. IX: 238)1.

\section{2: RUSKIN - 1904: „GIL BLAS”}

Proust's biographer, George D. Painter, notes that in the summer of 1902 Proust sent a manuscript of his translation of the The Bible of Amiens to Charles [!] Ollendorff, who kept the text for five months without being able to decide whether he would publish it or not, and afterwards he gave up the profession of a book publisher and became the owner of the 'Gil Blas' daily and his successor went bankrupt (Painter 1992: 370). The biographer also quotes the writer's letter from 1904 to Antoine Bibesco claiming that Proust's memory let him down as he complained about a year long absence of access to the manuscript and meanwhile it was already in the middle of December 1902 that he had it back at his disposal again, and signed an agreement with Le Mercure de France.

The issue is more complex and it has to be analyzed together with the cooperation with Ollendorff's daily „Gil Blas”, which took place in 1904. Painter writes that in the autumn of 1904 Proust had a 'minor flirtation' with the new "Gil Blas" daily, the competitor of „Figaro", whose owner was the same Paul Ollendorff (now, he is mentioned under his correct name) who did not

1 Proust signed this letter as: 'Your former collaborator Marcel Proust'. 
become the publisher of the The Bible of Amiens two years earlier (Painter 1992: 440). And so on September $9^{\text {th }}-$ I continue to recount after Painter - Proust was trying to persuade Antoine Bibesco to write about the début of Louise de Mornand in the Vaudeville, announced for September $16^{\text {th }}$, for "Gil Bas". Bibesco refused and Proust had to write the piece on his own, and then another one at the beginning of December. On December $14^{\text {th }}$, he published (under a pseudonym) a review of Fernando Gregh's book about Hugo. At the same time, Ollendorff refused to publish a dialogue entitled Vacances (Holidays), which later became a part of the series of novels in the form of the narrator's walk with Albertine in Bois de Boulogne.

Let us take a look at the documents, primarily Proust's correspondence.

In the letter to Georges Goyau, dated hypothetically at March 1904, and devised as a sophisticated acknowledgement for the received compliment, Proust wrote:

Dear Sir,

I wish to thank you wholeheartedly for the beautiful letter that you wrote to me. Your sweet praises are particularly dear to me:

Because only three or four people

Among whom also you are included

Can offer praise

In a manner that will last forever.

The word 'forever' could be used if your praise referred to Ruskin. (...) Unfortunately, I can sense that you like Ruskin only partially and I blame myself for it. I began by translating only a few extracts from 'The Bible of Amiens' which were chosen to give the loftiest idea of his work, those most worthy of his reputation and most characteristic of his genius. But a publisher, hearing of this, commissioned me to translate the whole of The Bible. Later this publisher went bankrupt (I am not talking about Mercure [de France]! here). But I completed the work for another publisher and meanwhile I took a fancy to it and did not have the courage to sacrifice even one of these beautiful nebulas on which I was trying to shed at least some light. And I would have been rewarded for such sacrifice. Every omitted boring fragment, every sacrificed gloomy page would change immediately into clean air that could be breathed, circulating between the selected pages and magnificent excerpts, putting them in their places and in the atmosphere adequate for them - like pedestals, highlighting the noble and solemn aspects 
in magical mirrors, which would recount the preserved fragments and multiplied their beauty forever.

But I did not do it and I have a feeling that this is not a book which could introduce people to Ruskin and win their hearts to him. Now, I am translating another one, much more attractive, simply a lecture - a long lecture about Reading (Sesame - of kings' treasuries); it does not have extended or weak fragments or ambiguities, and it is not overloaded with superficial archaeology and fanciful history and I believe that you will like it. But it is difficult to translate. What Verlaine said about humble life: 'the humble life with tedious, simple work is an act of choice and a deal of love it asks' may primarily apply to translation (Proust, Corr., Vol. IV: 79-80).

Let us start with the fact that the poem paraphrased at the beginning of the letter is the ending of the last verse of François de Malherbe's ode $\grave{A}$ la reine, mère du roi, sur le heureux succès de sa régence (1611), a verse starting with an invocation to Apollo, who allows for collecting the ever-green leaves with names which are going to be remembered forever, yet only few people (Malherbe proudly included himself among them) are able to make wreaths from them. The noun used in the phrase l'art d'en faire les couronnes in French means a wreath and a crown, which seems to make this verse a skilful allusion to the emblems of Henry III Valois, i.e. three crowns, symbolizing the kingdoms of France and the Commonwealth of Both Nations (Poland and Lithuania) and the motto Manet ultima caelo, accompanying it ('The last [crown] in heaven'2). Initially, Malherbe sought protection from Henry III, but he is also the author of an epigram criticizing his effeminate favorites ('Invective contre les Mignons d'Henri III').

When writing about capers with the publication of translation of Ruskin, Proust avoids names. The publisher notes in the commentary that it was Paul Ollendorff who ordered the translation for Société d'Édition Artistique; however, he later withdrew from the company, which led to its bankruptcy.

The second testimony that we have about this matter is the above-mentioned letter by Proust to Antoine de Bibesco dated at the evening of September $9^{\text {th }} 1904$.

2 On a side, it is worth noting that a reference to this idea is probably included in a poem by Słowacki Daję Wam tę ostatnią korone pamiątek... (I Give You This Last Crown of Souvenirs...). 
My dear Antoine,

I should be enormously grateful if you could get a message to Monsieur Ollendorff. It is to this effect. Some time ago, he had from me, by Picard, a dialogue which he had promised to print. Whether he prints it or not is a matter of complete indifference to me, but since the thing is 'set' in the month of September, I'd like him, if he doesn't hurry up, to let me have it back at once so that I may take advantage of its vaguely topical nature to get it placed elsewhere. All this must be told to him clearly and positively because, really, he is an impossible creature. My Ruskin was submitted to him for publication and it was a full year before I could get it returned. If it hadn't been that he resigned from the firm, and so been compelled (or rather, it was his successor who was compelled) to make a general clean-up, I doubt whether I should ever have set eyes again on that Bible of mine which he had at once so cruelly spurned and so jealously hung on to.

About that 'snapshop'. Louisa de Mornant took quite seriously what you probably meant as the vaguest of vague suggestions. You're the one who ought to do it. If you'd rather I took it over, nothing in the world will persuade me to sign it, because what's wanted is something incredibly vapid, a sort of pastiche of D. 'Remember this name: the day may come when the world will ring with it' - or 'she is mad about her art, and slaves at it unremittingly'. I think you could do it marvelously (Proust 1953: 130-131).

Proust mentions three texts in this letter. The first one was entitled Vacances: Françoise - Henri: premiers jours de Septembre (hence the words about its relative September validity) and was not published during Proust's lifetime; it was printed in 1949 by Harry Levin from the manuscript found in Harvard in the papers of Robert de Flers, to whom it was dedicated; in the Polish Plejada edition, it is entitled [Dialogue] and included in volume Contre Sainte-Beuve (Proust 1971: 431-435). The second text is the already mentioned translation of The Bible of Amiens, which was going to be published by Société d'Édition Artistique at the time when Ollendorff was the co-owner of this publishing house, but was finally published by Mercure de France. The third text to which a reference is made is a panegyric for a common friend of the addressee and the sender of the letter, i.e. the actress Louisa de Mornand (it was written by Proust and published by Ollendorff in "Gil Blas"), one of the few examples of the successful cooperation of the writer with this publisher. 
Meanwhile, at the beginning of October 1904, when sending to Antoine Bibesco his literary portrait, which was published in „Le Figaro” on October $8^{\text {th }}$, Proust wrote on the top of the first page of the manuscript: 'You did not tell me if you managed to recover my adorable Dialogue from Ollendorff's hands or receive a promise of its immediate publication' (Proust, Corr., Vol. IV: 312).

Additional light on the entire case was shed by Cynthia J. Gamble in her book devoted to Proust as the interpreter of Ruskin. She made an assumption that the translation that Ollendorff commissioned from Proust (who knew about his work on Ruskin from two articles which were published after the famous English thinker's death) encompassed a bare text of 'The Bible of Amiens', without notes and commentaries and possibly even only the (fundamental) fourth chapter. This assumption rests on the fact that Proust's translation was going to form a part of a series of translations of Ruskin's works published by Société d'Édition Artistique, a part of which was the translation of George Elwall which appeared in 1900, encompassing two works: La Couronne d'olivier sauvage and Les Sept lampes de l'architecture. At the time, when the translation by Proust was waiting in Ollendorff's files, he was continuing his work on Ruskin, writing commentaries. After receiving the text back from the publishing house, he submitted a corrected text together with lengthy comments to Mercure de France at the beginning of 1903.

It is interesting to note that Cynthia J. Gamble (2002: 89) found fragments of the above-mentioned translation of Elwall in Proust's papers. They include pages torn out from a printed book, but there are also the so-called 'long-galley proofs', signed by the translator and ready for print. How did they end up among Proust's papers? 'Did Elwall help Proust with translating The Bible of Amiens?' Did Proust treat Elwall as a potential competitor or a source of inspiration?' The researcher leaves these questions without a definite answer.

\section{8: NATANSON}

In 1908, Ollendorff's book store was mentioned in an article penned by Tadeusz Natanson, the husband of Misia née Godebska, in „Le Figaro” of April $29^{\text {th }}$ and devoted to the prose writer Octave Mirbeau. We know that Proust read this article due to the fact that in a letter to Gaston de Caillavet's 
wife, he recommended her to read it, laughing at the French style of writing of the Polish Jew Natanson (this resembles his remarks about French style of Prince Leon Radziwiłł presented in an unsent letter to the Prince, after reading his two texts in "Gil Blas” at the end of March and the beginning of April 1907):

Read the article at the head of this morning's Figaro. Any moment you expect to come across 'dog in the soup' etc. It lacks Gallicisms and it is truly comical not to find a single French phrase in three whole columns (Proust, Corr., Vol. VIII: 105) ${ }^{3}$.

This is what Natanson (1908: 1) wrote in this article:

It would seem to many of us that others feel the same emotions that overpowered us when we saw - in the period of the first Chronicles of the old „Echo de Paris” and Sébastien Roch - the man from whom we are learning to think and even to feel, as he crosses - carefully wrapped in a long cloak made of blue fabric with a velvet collar, Ollendorff's store at rue Richelieu, silent or speaking solemnly.

This excerpt shows Natanson's convoluted style, his peculiar choice of vocabulary and curious accumulation of pieces of information from completely different levels in one sentence, next to one another. However, it is extremely important for this argument as a testimony to the presence of Ollendorff's premises, a fixed point of reference in the landscape of the literary Paris at the end of the $19^{\text {th }}$ century.

\section{3: SWANN'S WAY}

When the attempt at publishing the first volume of the novel cycle with Fasquelle failed, Louis de Robert mentioned Alfred Humblot as an alternative to Proust; at that time, Humblot was the chief editor (directeur) in Ollendorff's publishing house, where he published Barrès, Régnier and Hermant, who were favorably inclined to Proust. At the beginning of January Humblot learnt that Proust was a great writer and that publishing his works would be an honor for the firm. A few days later Proust sent the manuscript without

3 Transl. after: http://www.yorktaylors.free-online.co.uk/caillav.htm [accessed: 20.09.2019]. 
mentioning - following Robert's advice - that it was already rejected by Fasquelle (Painter 1992: 640).

Humblot, relying on the opinion of Georges Boyer, a librettist and secretary general of the Parisian Opera, formulated an opinion to Louis de Robert, quoted with relish by Proustian experts, in particular American, as an extreme example of divergence between the publisher's opinions and the evaluation of posterity:

My dear friend, perhaps I am dense but I just don't understand why a man should take thirty pages to describe how he turns over in his bed before he goes to sleep (Proust, Corr., Vol. XII: 87).

Proust reacted to this opinion resolutely, describing Humblot's letter as 'completely stupid' (absolument stupide [Proust, Corr., Vol. XII: 84]); as for the essence, he wrote:

Indeed, in the first chapter I tried to present (I suspect that this is what [Humblot] wants to talk about, but I confess I have not recognized it) some half-dream impressions, the meaning of which will be explained later, but which went as far as my, quite modest, keenness allowed them. It is quite obvious that in this case it was not about stating that a man turns over in bed, and in fact fewer pages would have sufficed for that, but that this is only a means used for such analysis (Proust, Corr., Vol. XII: 84).

At the same time, Proust persuaded his friend not to end the cooperation with Humblot and the Ollendorff publishing house due to this. Having reconciled himself with the thought that he would have to publish the novel at his own expense in another publishing house, he did not reject the idea of publishing its fragments in "Gil Blas”. In an earlier letter to Louis de Robert, written probably around February $19^{\text {th }} 1913$, he advised his friend to keep the news about Ollendorff's refusal to himself, claiming that it was not about his offended self-love. He wrote:

I would not mention it to Blum either, maybe only about Fasquelle. Although he knows Olledorf[f]'s house intimately and also Mortier, so he will know (Proust, Corr., Vol. XII: 78).

Proust refers to René Blum (1878-1942), a critic, choreographer and future founder of Ballets Russes de Monte Carlo, brother of socialist politician 
Léon Blum. The word 'house' is to be understood as the 'publishing house' in this context. Pierre Mortier was the contemporary director of the "Gil Blas” daily where René Blum was an editor writing about art and theatre. Eventually, it was Blum who engineered the publication of Swann's Way in the company of Bernard Grasset.

\section{NEWCOMERS FROM RAWICZ}

It is time to move on to the Polish roots of the Ollendorff family, to which Proust was, as it turns out, related via various literary projects. The founder of the family was born in 1802 in Rawicz in Wielkopolska, probably as Hersz Gerszon. The name Ollendorff was not known in the area at that time. It was only around 1806 in Rawicz and in the near town of Sarne (Sarnowo), where two unrelated Jewish families, Gerszon and Pinkus, adopted the name Ollendorff. It is known that on September $17^{\text {th }} 1809$ a fire broke out in the house of inn-keeper Markus Ollendorff in Sarne, which destroyed a major part of the town, together with Polish, German and Jewish archives, due to which it is difficult to re-trace the earlier history of the family. Hersz Gerszon who is of interest to us, the son of a cloth merchant, signed his name Heinrich Gottfried Ollendorff; in England, he used names Henry Godfrey and in France Henri Godefroy. If he lived in Poland, he would undoubtedly be called Henryk Bogumił. He spent his childhood in Rawicz, but no details are unfortunately known about it. He left for London early, where he developed his own method of learning foreign languages. It relied on copying the manner in which the child learns the native language. Taking into account only the simplest grammar rules, the student - or actually the self-taught person - starts with simple sentences, consisting of a subject and object and gradually moves on to more complex structures. In 1830, Ollendorff moved to Paris and published, at his own expense, his phrase books for learning French, German, English, Italian, Spanish, Portuguese, Latin and various combinations among these languages. Materially stable, he decided to marry; to this aim, he returned to Rawicz and chose an adequate candidate, Dorothea Pinkus. The wedding took place in Cologne, half way between Rawicz and Paris. After the wedding, the couple and their children continued to visit the native village and according to family legend, local children would gather at the train station in Rawicz, shouting Da kommen die Pariser! - 'The Parisians are coming!'. However, this might be far from 
true, due to the fact that Ollendorff separated from Dorothea and managed to get married two more times before the railway line between Poznań and Wrocław was launched in 1856 and the railway station in Rawicz was opened - unless the story refers to the mother and sons ${ }^{4}$.

Heinrich Gottfried and Dorothea had three children: Minna, Gustave and Paul. Gustave (1850-1891) was a lawyer and a clerk in the department of fine arts and later in the ministry of trade. Well-built and handsome ('great torso, stalwart chest, healthy complexion, wavy hair and silky Titian-like beard, eyes ardent yet mild, lips stretched in an honest smile or vibrating under the pressure of numerous and quick words' [Henry 1892: 178-179]), he was distinguished by an extraordinary oratorical skill. He wrote about art (Parisian salons) and had friends among writers (V. Hugo). He played a significant role in preparations for the universal exhibition in Paris in 1889. He was friends with Charles Richet, a doctor (Nobel prize in 1913), who was also a writer (he published his books under the pseudonym of Charles Epheyre, in Paul Ollendorff's company), a pacifist and a Polonophile; in 1898, together with Proust he belonged to the group of first signatories of letters in defense of Dreyfus (see: Carroy 2004: 217-149) ${ }^{5}$.

Paul Ollendorff (1851-1920) developed the publishing house set up by his father, going far beyond the assortment of language phrase books. His books bore a large decorative sigil, composed of initials PO stylized to resemble old font, which may be interpreted as 'Paul Ollendorff', yet which may also indicate the country of origin of the family of book-sellers and publishers: 'POlogne'.

The program of the publishing house included such writers as Guy de Maupassant and Hugo (Ollendorff published all of his works in nineteen volumes, beautifully bound and richly illustrated). The flagship authors of the publishing house also included Gustave Ohnet, long forgotten today (1848-1918). In the times of Proust, he was a very popular author, which is

4 I used Bruck (1945) broschure and the unpublished biography of Ollendorff, written by Sergiusz Stema Wachowiak, made available to me by the director of the Museum of the City of Ostrów Wielkopolski, Witold Banach.

${ }^{5}$ It is worth adding that Richet and Maeterlinck are the co-authors of a brochure devoted to Poland under a meaningful title Poland for Poles (London 1916). 
testified by the conversation between Swann and Madame Cottard, included in the first volume of the series, devoted to two of his novels from the Les Batailles de la vie series: Serge Panine (1881) and Maître de Forges (1882). The title character from the first of them, in spite of the Russian-sounding name and surname, is a Polish prince, born in Wielkopolska and boasting of the fact that, as all Poles, he knew Latin very well.

Another author from the 'Ollendorff's literary stable' who published all of his French-language books in this publishing house, namely theatre plays, novels and volumes with literary sketches, was Stanisław Rzewuski (1864-1913). Proust knew him from „Le Figaro”, where Rzewuski managed the La vie littéraire à l'étranger section. Rzewuski was probably of interest to him as the nephew of Ewelina Hańska, whose painting collection Proust described in detail with clear admiration in Sainte-Beuve et Balzac (see: Proust 1971: 263-268).

At this moment, it is a good idea to go a step further and pose a hypothesis that Proust not only wrote advertising texts and articles for Ollendorff's paper, not only translated Ruskin for him, but received something from him in return. In a word: could it have happened that Proust, who knew German but not English from school, started to learn this language with the method developed by the publisher's father when attempting to translate Ruskin for Paul Ollendorff? This would explain why he was able, without any prior preparation, to translate two books of this difficult writer and, at the same time, why he had problems with talking with English people. Ollendorff's quick course, combined with high literary culture, allowed Proust to translate two works of Ruskin; Ollendorff's phrase books were good for holding a general conversation when travelling, yet not for intellectual debates on the level of The Bible of Amiens.

\section{1: $E C H O$}

A small piece written by Proust in 1911 is related to Ollendorff's phrase books. Echo is a pastiche of Pelleas and Mesalinde of Debussy based on a play of Maeterlinck. The key dialogue between Markel (contamination of the writer's own name with Arkel, the name of Pelleas' grandfather) and Pelleas (the model for whom was Reynaldo Hahn) sounds there as follows: 
Markel: You were wrong to leave that hat! You will never find it.

Pelleas: Why will I never find it?

Markel: One never finds anything again... here. It is lost forever.

Pelleas: As we go, we will find another which looks like it!

Markel: There are none which look like it!

Pelleas: What was it like then?

Markel (very quietly):

It was poor little hat

Like everyone wears!

No one could tell whose it was... It looked as though it came from the end of the world!

Now, we shall not look for it any longer because we will not find it.

Pelleas: It seems to me that my head is going to be cold forever. It is very cold outside. It is winter! If only the sun had not set. Why has someone left the window open? (...)

Markel: (...) It is too late. All the hats are gone. We cannot take anything else. It is a terrible thing, Pelleas.

But this is not our fault.

Pelleas: What is that noise?

Markel: The carriages are leaving.

Pelleas: Why are they leaving?

Markel: We will have scared them. They knew that we are going a very long way from here and they have left. They will never come back (Proust 1971: 206-207) ${ }^{6}$.

The dialogue refers - like conversations in Ollendorff's phrase books to banal, daily issues, e.g. a lost hat, yet in the course of time it shifts inconspicuously into the sphere of grotesque, with a vision of carriages scared of the prospect of a lengthy ride. Everything is instilled with nostalgia, the characters speak about the lost hat like a dead friend.

\section{IN WRITERS' EYES}

Ollendorff's phrase books intrigued writers. References to them helped gain greater popularity twice. The first reference is attributed to the Scottish author Basil Hall, a marine captain, who favorably mentioned the Ollendorff

6 Transl. after: http://www.yorktaylors.free-online.co.uk/pelleas.htm [accessed: 17.09.2019]. 
method in his diary about travels across Europe. The travelling started with meeting, half-way between Rome and Naples, a Polish friend with 'a name impossible to pronounce, Countess Rzewuska' (Hall 1838: 4) 7 . Artur Strindberg helped the second time. In one of his short-stories from a collection entitled Giftas (Getting Married, 1884), he introduced the motive of a progressive school for girls, where the girls, after two years of studying with the Ollendorff method, are speaking French fluently, whereas their peers from the male middle school are stammering after six years of learning with the use of traditional methods.

Among Polish writers Bolesław Leśmian had close contact with the phrase books due to the fact that his uncle published the Polish versions of Ollendorff's books, and it seems that the poet's father was helping him in this enterprise (see: Łopuszański 2003: 157-158). Also Henryk Sienkiewicz exchanged letters with Paul Ollendorff (about the French publication of Quo Vadis) and even wanted to take him to court. In this context it is worth mentioning that Proust personally knew one of the translators of Quo Vadis to French, Józef Władysław Janasz, and deeply regretted his suicide in 1905 (Proust, Corr., Vol. V: 311). Janasz is the author of a one-act play where the main character, Le Gentilhomme de Lettres, is modeled upon the young Marcel Proust.

\section{KORCZAK (?) - NEWERLY}

In 1906, the „Wędrowiec” weekly published an article signed with letters T.F.K. and entitled Ollendorff monstre. The whole text - stylistically close to Korczak - consists of a dialogue, resembling Ollendorff's phrase books, but containing a clear social and satirical undertones. When asked: 'And do you know who wrote... Agamemnon's Tomb?", the interlocutor provides a list of results of subsequent fights of strong men, resembling the style of Old Testament genealogical lists. The auto-thematic dialogue, starting with a question about the assembly-line production of gramophones, is quite characteristic too:

7 A chapter entitled The German Language (Hall 1838: 110-122) contains a praise of Ollendorff's method. The circumstances of Hall's invitation to Styria are presented differently by baron Purgstall-Hammer (1836). 
Have you ever been in a factory of gramophones when twenty-five gramophones are produced at the same time?

No, sir, but in any case I do not belong to any party. Politics bores me.

What?

Sir! Sir, you forget yourself! There is no 'what?' in any Ollendorff!

Never mind Ollendorff! Politics bores you! - well, well... (T.F.K. 1906: 193)

The dialogue follows the convention from Ollendorff's phrase books and, from simple questions and statements, transforms into absurd accusations. There is a colossal difference of cultural level and interests between the interlocutors, yet they are both trying to keep the conversation going in the mode imposed by the popular phrase books.

With respect to authorship, it is to be noted that Bara's dictionary does not list the abbreviation 'T.F.K... On the other hand, the tone of the dialogue resembles the chapter entitled Wykolejony (Derailed) from Janusz Korczak's novel Dziecko salonu (Child of the Drawing Room). In this chapter, the narrator starts chatting in French to a fat man who has just left the confectionery store with 'a package of cookies hanging from his button'. The dialogue is, in fact, a monologue in the form of questions and answers which starts with an innocent subject, such as parental love and cookies, and quickly moves on to drastic issues, such as venereal diseases and prostitution of children. The man with cookies finally speaks up and asks: 'Why don't you speak Polish?' and hears in response: 'Because you would not believe me... You are satiated: you do not know hunger and cold'. Here, a foreign language is the sign of education and good manners ('Oui, monsieur, I am a well educated child - un gentil homme. Only my pants are a bit torn and my soul is a bit frayed. Enfin...' [Korczak 1992: 351]). Another passage from the novel which corresponds to the article Ollendorff monstre is the chapter O gramatyce (On Grammars), i.e. a facetious apologia of grammar, made during a class with poor children at the Solec district in Warsaw, along the same principle which was the core of the philosophy behind the language teaching in the Ollendorff method: the analogy between the language, learning the language and personal development of a child.

The chapter Wykolejony ends with an autobiographical diary entry, in which the narrator writes: 'December $14^{\text {th }}$. I got seven rubles for the poems and the short story for the calendar'. When working on this text for the edition of Korczak's selected works, I put forward a hypothesis that 
the information may refer to 'two books for children, published at the end of 1902 by J. Guranowski, signed as 'Janusz', which Korczak used at that time as his pen name: Tylko dla grzecznych dzieci, powiastki i wierszyki and Króciutkie powiastki' (ibid. 522). Unfortunately, in spite of searches in the Polish and Russian libraries, it was impossible to find the copies of these items. Julian Guranowski, a publisher of calendars and books for children, was also the editor of „Wędrowiec", where the Ollendorff monstre humorous tale was published. Would he also this time be related to an unknown text by Korczak?

Into his late autobiographical novel entitled Zostało $z$ uczty bogów (It Remains of the Feast of the Gods), Igor Newerly incorporated several fragments of his first larger piece, the chronicle of a unit of Ataman Kotowski written in 1924 in Russian. The first fragment bears the title Komsek Johannes der Dritte (Ivanov Trzeci) and is a linguistic observation; it recounts the story of a commissar from Kotowski's brigade, who believes in an imminent war with the Germans and learns German from 'Olendorf phrase book' and rebukes his subordinates in this language: 'The sentences were correct, yet uttered in a mode as if they were read from a text written with Russian letters'.

Several years ago, the author of this paper managed to find the chronicle, entitled Kotowszczyzna, in one of the Russian magazines published before the war in Warsaw. The third chapter is entitled O tym, co wielkie, poprzez drobiazgi (On What is Great via the Sundries) It includes the above-mentioned anecdote about Komsek Johannes 'der Dritte' reading phrases from an Ollendorff phrase book. I tried to translate this piece, even though I am aware that its whole charm is in the version written in Cyrillic, when it is read by somebody who knows both Russian and German: 'He carefully flicked through the green book and was happy when he found something in it: »Remember that only at war das gebot der warhaftigkait (and he continued melodiously in inspired recitation) wi zo fille andre zittengebote ferliirt zajne gjultigkajt im krige!«? (In the footnote, Abugov/Newerly provides the actual meaning of the sentence in Russian: 'The commandment of veracity, similarly to many other ethical orders, loses its significance during war') ${ }^{8}$.

8 In this place, I am using relevant fragments of Newerly's biography (Zieliński 2012) with minor changes. 


\section{SŁONIMSKI - PARANDOWSKI}

Antoni Słonimski, in the adventure novel published in 1925 and entitled Pod zwrotnikami. Dziennik okrętowy (Under the Tropics. The Ship Diary) included the following passus:

Apart from it, the Englishman entertains little Françoise with boring questions that smell like conversations from Ollendorff's phrase books: 'Can you tell me which fruit do you like the most? Pears, plums or nuts?' According to Ollendorff, the girl should answer: 'There are many apples in my uncle's garden'. Françoise simply says that she does not like fruit. The Englishman became silent and sat without a word through the whole dinner, but when fruit was served after dessert, he grabbed an apple from Françoise's place and said giggling: 'As you said that you did not like apples, I will eat your apple'. It seems to me that he is not an idiot, but I may be mistaken. In any case, the English jokes that I adore are quite eccentric (Słonimski 1925: 135).

In the novel The King of Life written between 1928 and 1929, where Oscar Wilde is the main character, Jan Parandowski introduced a comparison to Ollendorff's phrase books when discussing the language of the play Salomé, written in French. He quotes the question of Stuart Merrill '(...) don't you think that the characters in your play speak like English children who had a French tutor?' and the author's reaction:

Wilde smiled.

'You talk like a true friend'.

He took the manuscript, said goodbye, and left. He knew what to think about it. His prose was simple; he knew that he should not get entangled in lengthy sentences, but he did not take it from Ollendorff's phrase books. He took it from Maeterlinck's The Seven Princesses and was happy that Merrill did not look through it (Parandowski 1955: 247)9.

9 These names may be found in Robert Ross' foreword to the English edition: 'Our old friend, Ollendorff, definitely comes to mind when you read Wilde's French writings; similarly to any other early plays of Mr. Maeterlinck' (Wilde 1912). Moreover, it is known that in prison, Wilde read Faustus with Ollendorff's phrase book in hand. 
This example testifies to the ambiguous relations between some literary texts, written in languages other than the native ones, and the style of Ollendorff's phrase books.

\section{WINAWER - STEMPOWSKI}

In 1932, Bruno Winawer, a writer and promoter of science, in an article entitled Drugi sad nad Sokratesem (The Second Socrates' Trial) wrote, referring to the book of Alexander Moszkowski Sokrates, der Idiot, about the style of Plato's dialogs and their 'non-academic nature':

Who is going to carefully read such lengthy sentences as: 'You conceded, Crito, that death is born from life and life results from death, thus you also have to concede'... etc. calls after Moszkowski, calls after the kind Xanthippe, after Aristophanes: amen to that! Socrates was a truly noisy machine, set for slow motion (Leerlauf), he did not perform any work, his questions and answers resemble the famous conversations from Ollendorff's phrase books or arguments of lawyers in Dickens' books... (Winawer 1932: 1).

In 1961, Jerzy Stempowski entitled one of his pieces in the Notatnik niespiesznego przechodnia' series, published in the Parisian „Kultura” under the pseudonym of Paweł Hostowiec, Rozmówki Ollendorfa (Ollendorff's Phrase Books). This title serves as a pretext, due to the fact that the actual subject matter of the piece is the Polish and Russian dialogue during emigration; however, in the context of our subject matter, it is worth quoting the beginning of Stempowski's text:

A number of years ago - I remember vaguely - phrase books created by one Ollendorff were used to learn German; they were the source of fun for both young and old people. The conversations in these phrase books, initially terrifyingly banal, became weird as the learner's vocabulary expanded, as if taken from some difficult-to-imagine situations. 'Where is our neighbor?' - 'Our neighbor in on the roof'. - 'What did your nephew sit on?' - 'Your nephew sat on your wig'. In other circumstances, exchanging such statements would upset some, yet in this case the content of questions and answers was eventually indifferent; it was about learning a certain amount of words and phrases which could later be used for an actual conversation. 
Every time I think about Polish and Russian conversations at emigration,

Ollendorff's phrase books come to my mind (Stempowski 2012: 242) .

Stempowski's procedure consists in referring the current situation to the phenomenon drawn from a distant, but personally experienced past and, taking this opportunity, re-living that phenomenon, as well as many others with respect to which he had a feeling that he might possibly be the last person who remembers them. Certain cultural mechanisms are activated here; there is also a feeling of uniqueness of the experience resulting from longevity and richness of multicultural experiences.

$* * *$

As commonly known, Proust's works were eventually published by Gallimard. Nevertheless, this was not always the case and the story could have taken a different turn. The history of ties with the Ollendorff family from Rawicz shows various aspects of Proust's works in a new light and induces one to wonder which other Polish threads could have possibly appeared in a more open and explicit mode in the In Search of Lost Time if the title page of individual volumes bore the printer's device with the 'PO' letters, stylized to resemble old font. PO meaning POlogne.

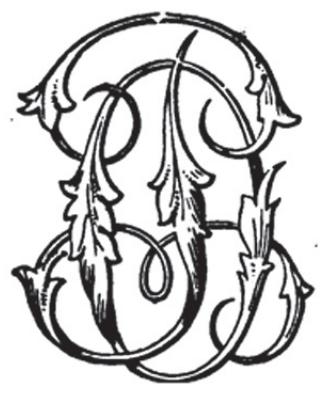

Fig. 1. The signet of the Paul Ollendorff's publishing house

10 It is worth noting that Jerzy Timoszewicz reprinted two other articles from this issue - Gdzie umieścić Czycza and Do Kazimierza Wierzyńskiego - in earlier selections of Stempowski's essays $(1988,2001)$, whereas the above-quoted one waited for the reprint for over half a century. 


\section{Bibliography}

Antoine Bertrand (1966), Les curiosités esthétiques de Robert de Montesquiou, Vol. II, Genève: Librairie Droz.

Alfred Julius Bruck (1945), The Ollendorff Family. A Historical Sketch, New York. Jacqueline Carroy (2004), Playing with Signatures. The Young Charles Richet, [in:] The Mind of Modernism: Medicine, Psychology and the Cultural Arts in Europe, 1880-1940, ed. M.C. Micale, Redwood City: Stanford University Press. Cynthia J. Gamble (2002), Proust as Interpreter of Ruskin: The Seven Lamps of Translation, Birmingham: Summa Pubns.

Basil Hall (1838), Schloss Hainfeld, Or: A Winter in Lower Styria, Edinburgh: Robert Cadell.

Lucien Henry (1892), M. Ollendorff, 'Bulletin annuel - Association amicale des secrétaires et anciens secrétaires de la Conférence des avocats à Paris'.

Janusz Korczak (1992), Dzieci ulicy. Dziecko salonu, Warszawa: Oficyna Wydawnicza Latona.

Piotr Łopuszański (2003), Z rodu księgarzy - warszawskie korzenie Bolesława Leśmiana, „Pamiętnik Literacki”, Vol. 3.

Thadée Natanson (1908), Octave Mirbeau, „Le Figaro”, issue frum April 29th

George D. Painter (1992), Proust, transl. G. Cattaui et R.-P. Vial, Paris: Mercure de France.

Jan Parandowski (1955), Król życia, [in:] idem, Pisma wybrane, Warszawa: Czytelnik. Marcel Proust (1953), Letters of Marcel Proust to Antoine de Bibesco, transl. G. Hopkins, London: Thames and Hudson.

Marcel Proust (1971), Contre Sainte-Beuve, Paris: Gallimard.

Marcel Proust (1971a), Jean Santeuil, précédé de Les Plaisirs et les jours, Paris: Gallimard.

Marcel Proust (1970-1993), Correspondance, Vol. I-XXI, Paris: Plon. Joseph von Purgstall-Hammer (1836), Ueber Capitäns Hall Buch: Schloß Hainfeld, „Blätter für Literatur, Kunst und Kritik”, issue from August $10^{\text {th }}$.

A. Słonimski (1925), Pod zwrotnikami. Dziennik okrętowy, Warszawa: Gebethner i Wolff.

Jerzy Stempowski (1988), Szkice literackie, Vol. II: Klimat życia i klimat literatury, Warszawa: Czytelnik.

Jerzy Stempowski (2012), Rozmówki Ollendorfa, [in:] idem, Notatnik niespiesznego przechodnia, Vol. 1, Warszawa: Biblioteka „Więzi” (first print: „Kultura” 1961, No. 7-8, p. 165). 
T.F.K. (1906), Ollendorff monstre, „Wędrowiec”, No. 10

Oscar Wilde (1912), Salomé, London - New York: John Lane, The Bodley Head. Bruno Winawer (1932), Drugi sąd nad Sokratesem, „Wiadomości Literackie”, No. 12. Jan Zieliński (2012), Szkatułki Newerlego, Warszawa: W.A.B.

\section{Summary}

The first part of the paper discusses the meanders of collaboration between Marcel Proust and Paris-based publisher Paul Ollendorff that spanned over twenty years (1893-1913). Further on, Western expansion of the Ollendorff family from Rawicz, Poland, is briefly sketched. Another passage concerns a Maeterlinck pastiche by Proust (Echo, 1911), seen in the context of Ollendorff's conversation-based method of learning foreign languages. The author suggests Proust was using this method to learn English himself. The paper ends with a survey of several references to the Ollendorff method in the twentieth century Polish prose.

Keywords: Proust, the Ollendorffs, self-study guides, phrase books, conversational method, pastiche, comparative literature. 